\title{
Functional Age Predicted by Electronic Short Physical Performance Battery Can Detect Frailty Status in Older Adults [Corrigendum]
}

Jung HW, Jin T, Baek JY, et al. Clin Interv Aging. The authors apologize for this error. 2020;15:2175-2182.

Page 2180, Acknowledgments, line 5, the text "2018IF0143" should read "2018IF0413".

\section{Publish your work in this journal}

Clinical Interventions in Aging is an international, peer-reviewed journal focusing on evidence-based reports on the value or lack thereof of treatments intended to prevent or delay the onset of maladaptive correlates of aging in human beings. This journal is indexed on PubMed Central, MedLine, CAS, Scopus and the Elsevier
Bibliographic databases. The manuscript management system is completely online and includes a very quick and fair peer-review system, which is all easy to use. Visit http://www.dovepress.com/ testimonials.php to read real quotes from published authors. 